Sonia Jarzombek-Ziemiańska

Szkoła Podstawowa Specjalna nr 2 w Bytomiu, Wyższa Szkoła Humanitas w Sosnowcu E-MAIL: sonia.jarzombek@gmail.com

\title{
Znaczenie terapii integracji sensorycznej w funkcjonowaniu dzieci ze spektrum autyzmu w normie intelektualnej (na przykładzie uczniów Szkoły Podstawowej Specjalnej nr 2 w Bytomiu)
}

\begin{abstract}
STRESZCZENIE
Szkoła Podstawowa Specjalna nr 2 w Bytomiu to miejsce nauki dla uczniów w normie intelektualnej ze spektrum autyzmu i z niedosłuchem. W ramach zajęć rewalidacyjnych prowadzony jest szereg urozmaiconych terapii. Przeprowadzono badania w celu określenia jakości terapii Integracji Sensorycznej na funkcjonowanie i postępy edukacyjne uczniów. Otrzymane wnioski z badań są podstawą do określenia dalszej formy pracy terapeutycznej.

SŁOWA KLUCZOWE: autyzm, zaburzenia integracji sensorycznej, zaburzenia odruchów pierwotnych, terapia
\end{abstract}

\section{Wprowadzenie}

Jest takie miejsce na Śląsku, gdzie dzieci i młodzież w normie intelektualnej ze spektrum autyzmu i niedosłuchem mają możliwość uczyć i rozwijać się w szkole dla nich przyjaznej i przystosowanej, czyli Szkole Podstawowej Specjalnej nr $2 \mathrm{w}$ Bytomiu. Powołano ją do życia 6 lat temu, chociaż od lat $\mathrm{w}$ swoich murach wykształciła wiele pokoleń z każdego poziomu edukacji. Dyrektor dr Iwona Wanda Grygiel i wicedyrektor mgr Izabela Szynal to osoby o nieprzeciętnej osobowości i potencjale. Dbają o rozwój szkoły, by uczniowie mieli jak najlepsze warunki do edukacji i rozwoju. Mam przyjemność pracować w tej szkole od 5 lat.

W ramach zajęć rewalidacyjnych $\mathrm{w}$ naszej szkole prowadzone są różne terapie. Ich zakres jest bardzo szeroki i wynika z wykształcenia, umiejętności i doświadczenia kadry. Oferujemy naszym uczniom głównie terapie: psychologiczną, logopedyczną, behawioralną, Integracji Sensorycznej, odruchów pierwotnych, bilateralną, neurokinezjologiczną, Biofeedback, Warnkego, 
czaszkowo-krzyżową, arteterapię, dogoterapię, czy szeroko rozumianą rewalidację. Ponadto, mamy w pełni wyposażone sale do terapii Integracji Sensorycznej, Doświadczania Świata, SITA. Niektóre klasy są dostosowane do potrzeb dzieci z zaburzeniami percepcji słuchowej. W ramach zajęć dodatkowych uczniowie mogę rozwijać się w sekcji szachów, brydża sportowego i robotyki, a także brać udział w niesamowitej podróży, jaką gwarantuje udział w programie Odyseja Umysłów.

Duża część uczniów objęta jest terapią Integracji Sensorycznej¹, która jest jednym $\mathrm{z}$ zaleceń spotykanych $\mathrm{w}$ orzeczeniach o kształceniu specjalnym. U dzieci ze spektrum autyzmu często występują zaburzenia przetwarzania zmysłowego, a tym samym nieharmonijny rozwój. By uczniowie mogli czerpać jak najwięcej korzyści terapeutycznych, staramy się dopasować zajęcia rewalidacyjne do ich potrzeb.

W swojej praktyce obserwuję jednak coraz częstsze zjawisko występowania zaburzeń w tym obszarze. Stąd pojawiły się pytania z zakresu naukowo-empirycznego:

- Co oprócz zaburzeń integracji sensomotorycznej może mieć wpływ na nieharmonijny rozwój dziecka?

- Jak można wspomóc rozwój dziecka w warunkach szkolnych?

\section{Znaczenie Integracji Sensorycznej}

Czym jest zatem Integracja Sensomotoryczna? „Integracja czynności zmysłowo - ruchowych jest to proces, w którym mózg informacje z narządów zmysłów przyjmuje, rozpoznaje, segreguje, interpretuje, integruje z już posiadanymi, zapamiętuje je (rejestruje, koduje), aby odpowiedzieć właściwą reakcją. Odpowiedzi te rozwijają się i doskonalą wraz z dojrzewaniem człowieka oraz indywidualnymi doświadczeniami i nabywaną wiedzą" (Borkowska i Wagh, 2010, s. 12). Tak wygląda przebieg prawidłowego procesu integracji sensomotorycznej u dziecka. Występowanie zaburzeń integracji sensorycznej to problem złożony. Wpływa na wszystkie procesy rozwojowe i społeczno-emocjonalne dzieci. Szczególnie zauważalne jest w rozwoju i zachowaniu dziecka, w procesie uczenia się i komunikowania ze światem, a także w budowaniu dziecięcych przyjaźni i wchodzeniu w role społeczne. Wspólnym problemem są zaburzenie przetwarzania sensorycznego, czyli brak umiejętności wykorzystywania otrzymanych przez zmysły informacji w celu płynnego, codziennego funkcjonowania. Zaburzenia przetwarzania sensorycznego mają 
miejsce w centralnym układzie nerwowym, którym kieruje mózg. Jeśli przetwarzanie przebiega nieprawidłowo, wówczas mózg nie jest w stanie spełnić swej najistotniejszej funkcji, którą jest organizacja informacji sensorycznych. Dziecko nie jest w stanie zareagować na informacje sensoryczne znaczącym, spójnym zachowaniem. Może mieć też problem z zaplanowaniem i zrealizowaniem swoich działań oraz z wykorzystaniem i przetworzeniem informacji sensorycznych. Stąd uczenie się może sprawiać dziecku trudność (Kranowitz, 2012, s. 31-32).

Zaburzenia przetwarzania sensorycznego można podzielić na kategorie i podtypy. Rysunek 1 przedstawia złożoność zaburzeń wynikających z przetwarzania sensorycznego. Najczęstszym obserwowanym objawem są zaburzenia modulacji sensorycznej. Modulacja rozumiana jest jako proces zachodzący w ośrodkowym układzie nerwowym, podczas którego impulsy nerwowe są wzmacniane lub wyhamowywane. Jeżeli proces ten przebiega prawidłowo to nasze reakcje na docierające bodźce sensoryczne są płynne i adekwatne do ich intensywności.

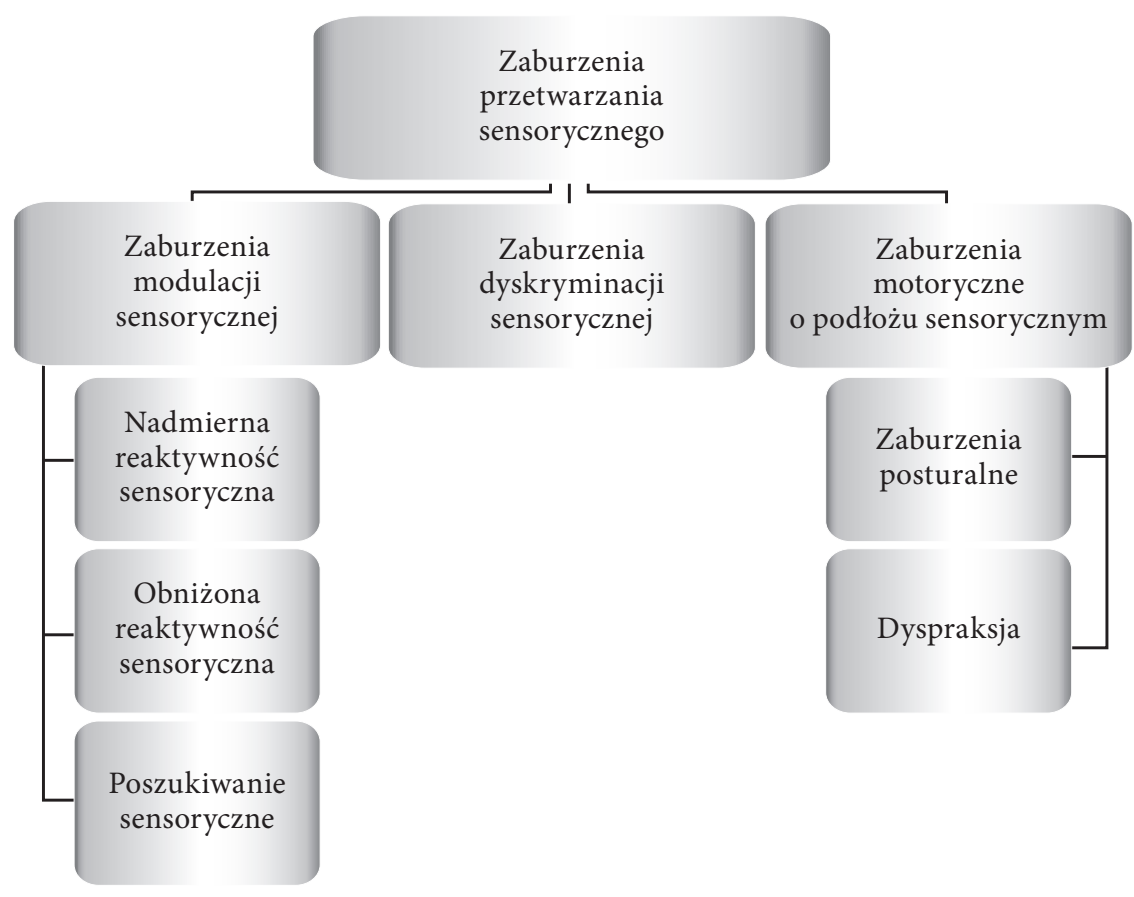

Rysunek 1. Kategorie i podtypy zaburzenia przetwarzania sensorycznego

Źródło: opracowanie własne na podstawie C.S. Kranowitz (2012, s. 33) 
Dzieci charakteryzujące się nadmierną reaktywnością będą głównie unikały doznań zmysłowych. Mają także nadreaktywny układ współczulny, który najczęściej jest nastawiony na sytuację „walki bądź ucieczki”. Takie dzieci unikają dotykania, brudzenia się, źle reagują na sytuacje nieoczekiwane, czują się mało bezpiecznie, gdy ktoś nagle je dotknie bądź poruszy. Bywają usztywnione i nieskoordynowane, dlatego unikają zabaw, podczas których ich mięśnie odbierają wrażenia zmysłowe. Za to nadmierne podekscytowanie może pojawić się, gdy w polu widzenia jest zbyt duża ilość bodźców wzrokowych, co wywołuje najczęściej dekoncentracje, rozkojarzenie i problemy z przyswajaniem wiedzy. W ramach tego zaburzenia można zaobserwować nadwrażliwość słuchową i dźwiękową. Zmysł zapachu również jest wyostrzony i ma wpływ na tolerancję zapachową niektórych osób, miejsc czy przyjmowanie pokarmów. To ostatnie często jest zauważalne u tej grupy dzieci i łączy się z nietolerancją na konsystencje przyjmowanych pokarmów czy ich temperaturę.

Przeciwieństwem tej grupy są dzieci z obniżoną reaktywnością sensoryczną. Najczęściej są to dzieci, które nie zauważają czegoś, ignorują, nie mają wewnętrznego napędu bądź wewnętrznego imperatywu do działania czy zabawy. $Z$ wielu sytuacji i rzeczy nie zdają sobie sprawy. Nie zauważają, że są brudne. Dziecko reaguje na wrażenia z mniejszą intensywnością, potrzebuje mocniejszej stymulacji, by osiągnąć zwykły poziom pobudzenia.

Trzecia gałąź zaburzeń modulacji to poszukiwacze sensoryczni wszelkich doznań, często też niebezpiecznych. Często dzieci z tej grupy postrzegane są jako „żywe srebro" z nadpobudliwością psychomotoryczną.

Innym elementem zaburzeń występujących $\mathrm{w}$ integracji sensorycznej jest dyskryminacja sensoryczna polegająca na trudności odróżnienia, zidentyfikowania i przetwarzania wrażeń sensorycznych, od tego co pierwotnie powinny oznaczać. Problemy motoryczne w SI mogą mieć podłoże w zaburzeniach posturalnych, obejmujących problemy z równowagą, koordynacją, lateralizacją czy powtórzeniem wzorca ruchu. Występuje tu także dyspraksja charakteryzująca się brakiem zdolności planowania i wykonania celowych ruchów.

Z pomocą takim uczniom przychodzi terapia Integracji Sensorycznej, która opiera się na wzmacnianiu odbioru sensorycznego danej osoby. Według Jean Ayres „integracja sensoryczna to możliwość rejestrowania informacji ze świata zewnętrznego przez narządy zmysłów, ich przetwarzanie w ośrodkowym układzie nerwowym i wykorzystanie do celowego działania" (Mass, 2007, s. 32). Podstawą terapii jest proces diagnostyczny i opracowanie zaleceń oraz tzw. diety sensomotorycznej. Praca terapeutyczna skupiona jest na 
systematycznym i odpowiednim stymulowaniu wskazanego układu sensorycznego: dotykowego, proprioceptywnego oraz przedsionkowego (Mass, 2016, s. 30) oraz motoryki. Dzięki wykorzystaniu neuroplastyczności układu nerwowego, pobudzaniu neuronów mózgu dziecka do prawidłowego rozwoju można uzyskać harmonijny rozwój od pnia mózgu do wyższych struktur kory mózgowej.

\section{Analiza procesu badania i uzyskanych wyników}

$\mathrm{Na}$ przestrzeni kilku lat pracy w szkole zauważam, jak duże znaczenie ma terapia SI dla rozwoju i edukacji uczniów. Do przeprowadzenia diagnozy z zakresu zaburzeń Integracji Sensorycznej wykorzystano:

- Kwestionariusz Integracji Sensomotorycznej Z. Przyrowskiego - to narzędzie, które na podstawie określonych zachowań pozwala ocenić ryzyko zaburzeń Integracji Sensorycznych u dzieci;

- Południowokalifornijską Baterię Testów dr J. Ayres służącą do diagnozy podstawowych parametrów percepcyjno- motorycznego funkcjonowania dziecka;

- Kwestionariusz ustrukturyzowanego wywiadu diagnostycznego w kierunku zespołu nadpobudliwości psychoruchowej (ADHD) według ICD10 i DSM-IV TR - uzupełniający proces diagnostyczny;

- wywiad z rodzicem i obserwację terapeutyczną.

Przeanalizowałam proces diagnostyczny, jaki przeprowadzono na początku roku szkolnego 2019/2020 u 16 uczniów klas 1-3 ze spektrum autyzmu. Klasy terapeutyczne dla uczniów ze spektrum autyzmu są 4 osobowe (Dz.U. 2019 poz. 502). Uczniowie objęci diagnozą są to chłopcy w wieku 7-10 lat. Większość z nich, bo 10, przejawia zaburzenia uwagi przekładające się szczególnie na skupienie, wytrwałość czy koncentrację podczas lekcji. Poziom przyswajania materiału edukacyjnego i tempo pracy są $\mathrm{w}$ tej grupie bardzo różne i nieharmonijne. Obserwuje się problemy z motoryką małą, precyzją i dokładnością. W obrębie motoryki dużej najczęstszym problemem jest brak koordynacji lateralnej, równowagi i niepewność grawitacyjna. Występują także zaburzenia zachowania najczęściej ujawniające się w nieumiejętności opanowania i przestrzegania zasad moralnych i norm panujących w szkole oraz domu rodzinnym. U 5 uczniów występują zachowania agresywne, a u 4 autoagresywne. Zaburzenia opozycyjno-buntownicze pojawiają się u 6 uczniów. Natomiast zachowania na odmowę współpracy występują u 9 chłopców. Impulsywność jest charakterystyczna dla 8 uczniów. Grupa ta charakteryzuje się również 
labilnościami emocjonalnymi, problemami z inicjacją i podtrzymywaniem prawidłowych kontaktów społecznych oraz zauważa się obniżone poczucie własnej wartości.

Zaburzenia Integracji Sensorycznej w badanej grupie często mają formę mieszaną. Nieprawidłowości integracyjne przejawiają się szczególnie w problemach z modulacją sensoryczną. Jej nadreaktywność przejawia się u 5 chłopców, podreaktywność u 7, a tak zwanych poszukiwaczy wrażeń sensorycznych jest 4. Problemy z dyskryminacją sensoryczną występują u 6 uczniów. Zaburzenia motoryczne o podłożu sensorycznym są widoczne u 7 dzieci. Najczęściej przejawiają się w koordynacji jedno i obustronnej, przekraczaniu linii środka ciała czy objawami dyspraksji.

Najwcześniej dojrzewającym pierwotnym systemem jest dotyk zwany taktylnością. Układ ten ma wpływ na fizyczne, psychiczne i emocjonalne zachowania człowieka. Dotyk jest źródłem istotnych informacji dla świadomości własnego ciała, planowania motorycznego, dyskryminacji wzrokowej, języka, szkolnego uczenia się, bezpieczeństwa emocjonalnego i umiejętności społecznych (Kranowitz, 2012, s. 87). Problemy z taktylnością występują u 11 uczniów.

Z badań wynika, że zaburzenia występują także w obrębie układu proprioceptywnego odpowiedzialnego za czucie głębokie u połowy badanych (8 chłopców). Wrażenia płynące z tego układu informują nas o ruchach i pozycji ciała. Propriocepcja to zmysł pozycji lub zmysł mięśniowy. Najwięcej wrażeń dociera do nas wtedy, gdy aktywnie naciągamy lub kurczymy mięśnie podczas ruchów przeciw sile grawitacji (Kranowitz, 2012, s. 126-127).

Ostatni z ważnych systemów w rozwoju człowieka to system przedsionkowy zwany zmysłem równowagi, który znajduje się w uchu wewnętrznym. Receptory układu przedsionkowego uważane są za najbardziej wrażliwe spośród wszystkich narządów zmysłów. Doznania płynące z wykonywanych przez dziecko ruchów umożliwią mu coraz lepsze poznanie własnego ciała, jego granic i możliwości oraz relacji z otoczeniem ${ }^{2}$. W obecnej chwili system ten nie zintegrował się nadal u 9 uczniów.

$\mathrm{Na}$ podstawie materiału diagnostycznego przygotowano indywidualne plany terapeutyczne i prowadzono systematyczną cotygodniową terapię. Ze względu na wprowadzenie w marcu 2020 roku nauczania zdalnego w związku z ogłoszoną pandemią COVID-19 wstrzymano dotychczasowe zajęcia tera-

2 Informacje pochodzą ze strony http://www.pstis.pl/pl/html/index.php?str=podstrona slownik 
peutyczne stacjonarne $\mathrm{w}$ szkole. W systemie nauczania zdalnego przesyłano zalecenia do pracy w domu.

W czerwcu 2020 roku przeprowadzono planowaną rediagnozę. Do rediagnozy zastosowano kwestionariusze stosowane w początkowej fazie oceny.

\section{Podsumowanie badań i plany na przyszłość}

Podsumowując otrzymany materiał rediagnostyczny można stwierdzić, że uczniowie $\mathrm{z}$ badanej grupy mający także diagnozę zaburzenia ze spektrum autyzmu przejawiają nadal widoczne zaburzenia w Integracji Sensorycznej. Zauważalną poprawę zaobserwowano u $4 \mathrm{z} 7$ uczniów z podreaktywnością (57\%), 2 z 4 poszukujących wrażeń (50\%) i 2 z 5 z nadraktywnością (40\%). System dotykowy wzmocnił się u $5 \mathrm{z} 11$ uczniów (45\%), proprioceptywny u 3 z 8 (38\%), a przedsionkowy u 4 z 9 (44\%).

Praca terapeutyczna przełożyła się także na jakość funkcjonowania w zespole klasowym. Zwiększył się poziom wytrwałości i skupienia na zadowalający. Zaobserwowano też pozytywne efekty w zachowaniu uczniów i w ich funkcjonowaniu społecznym. U 2 z 10 (20\%) uczniów zmniejszyły się zaburzenia uwagi. Poziom agresji zmniejszył się u 2 z 5 (40\%), a autoagresji u 1 z 4 (25\%). Zachowania opozycyjno-buntownicze zanotowano u 4 z 6 uczniów (57\%), a na tzw. odmowę u 6 z 9 (67\%). Efekty uzyskano także w zmniejszeniu impulsywności uczniów u 2 z 8 (25\%).

Na podstawie obserwacji terapeutycznych oraz wypowiedzi rodziców uczniów i ich samych stwierdza się, że w trybie nauczania zdalnego, głównie ze względu na brak odpowiedniego sprzętu terapeutycznego w domach rodzinnych uczniów i odpowiedniego przygotowania terapeutycznego rodziców, terapia SI najbardziej efektywna jest prowadzona na sali SI.

W dalszym ciągu należy pracować nad poprawą prawidłowego działania układów przedsionkowego, taktylnego i proprioceptywnego. Jakość pracy tych systematów przekłada się na prawidłową modulację sensoryczną i będzie rzutować na specyfikę funkcjonowania uczniów w systemie szkolnym, ich rozwój emocjonalno-społeczny i zachowanie.

Świadomość złożoności tego zjawiska została potwierdzona w wynikach badań i jest odpowiedzią na stawiane sobie na początku badania pytanie o to, co zakłóca harmonijny rozwój dziecka.

Zauważono, że u 14 z 16 (13\%) uczniów nadal współwystępują zaburzenia z zakresu niedojrzałości neuromotorycznej objawiające się przetrwałymi odruchami pierwotnymi. Zintegrowany zestaw odruchów pierwotnych jest podstawą rozwoju i ma na celu zapewnienie natychmiastowej reakcji na nowe środowisko i zmieniające się potrzeby. Odruchy pierwotne to automatyczne, 
stereotypowe ruchy powstające na poziomie pnia mózgu i wykonywane bez udziału kory mózgowej (Goddard Blythe, 2018, s. 23). Dlatego też prawidłowe funkcjonowanie neuromotoryczne jest jednym ze wskaźników dojrzałości ośrodkowego układu nerwowego. Jest również powiązane z integracją sensoryczną, a w szczególności z układem przedsionkowym, proprioceptycznym i posturalnym. (Goddard Blythe, 2015b, s. 18). Na podstawie tych informacji podjęto decyzję, by $\mathrm{w}$ dalszej części kontynuować badania $\mathrm{w}$ poszerzeniu o rozwój odruchów pierwotnych.

Nietypowa i niespodziewana zmienna, która wystąpiła w postaci epidemii COVID-19 i sytuacji społeczno-gospodarczej, z jaką mieliśmy do czynienia w marcu 2020 roku częściowo zmieniła prowadzone terapie w tryb zdalny.

Odpowiedź na drugie pytanie badawcze: „Jak można wspomóc rozwój dziecka w warunkach szkolnych?" wynika $\mathrm{z}$ analizy zebranego materiału rediagnostycznego i obserwacji terapeutycznych. Dalsza praca diagnostyczna i terapeutyczna będzie kontynuowana wraz z początkiem nowego roku szkolnego po powrocie do nauczania stacjonarnego. Już teraz wiem, że badania będą kontynuowane $\mathrm{w}$ formie poszerzonej o wprowadzenie do diagnozy SI także Szkolnego Programu Ćwiczeń Integrujących INPP opracowanego na podstawie testów Sally Goddard Blythe. Kieruję się tu faktem, że zrozumienie uniwersalnego i holistycznego charakteru prawidłowego rozwoju i rządzących nim mechanizmów daje możliwość zbudowania odpowiedniego programu stymulacji ruchowej i sensorycznej dla uczniów (Goddard Blythe, 2018, s. 141), co jest celem nadrzędnym. Szczególny nacisk będzie kładziony na zrównoważenie Asymetrycznego Tonicznego Odruchu Szyi (ATOS), Symetrycznego Odruchu Szyjnego (STOS) i Tonicznego Odruchu Błędnikowego (TOB), czyli pierwotnych tonicznych odruchów szyjnych i błędnikowych, gdyż one najczęściej były zauważalne w badanej grupie. To one głównie działają i odzwierciedlają funkcjonowanie układu przedsionkowego i jego współpracę z innymi mechanizmami odbierającymi zmianę położenia i ruchu (Goddard Blythe, 2015b, s. 28).

Można przyjąć założenie, że kontynuacja badań z zakresu zwiększenia skuteczności terapii SI w połączeniu ze Szkolnym Programem Ćwiczeń Integrujących INPP $\mathrm{w}$ formie eksperymentu pedagogicznego podniesie jakość, tempo i efekty edukacyjno-terapeutyczne przekładające się na wyniki w nauce i rozwój emocjonalno-społeczny naszych uczniów.

\section{BIBLIOGRAFIA}

Borkowska, M. (2018). Integracja sensomotoryczna w rozwoju dziecka. Gdańsk: Harmonia Universalis. 
Borkowska, M. i Wagh, K. (2010). Integracja sensoryczna na co dzień. Warszawa: Wydawnictwo Lekarskie PZWL.

Goddard Blythe, S. (2018). Odruchy, uczenie się i zachowanie. Warszawa: PWN.

Goddard Blythe, S. (2015a). Jak ocenić dojrzałość dziecka do nauki? Warszawa: PWN.

Goddard Blythe, S. (2015b). Niedojrzałość neuromotoryczna dzieci i dorostych. Warszawa: PWN.

Kranowitz, C.S. (2012). Nie-zgrane dziecko. Gdańsk: Harmonia Universalis.

Kuleczka-Raszewska, M. i Markowska D. (2012). Uczę się poprzez ruch. Gdańsk: Harmonia Universalis.

Odowska-Szlachcic, B. (2018). Terapia integracji sensorycznej. Zeszyt 1 i 2. Gdańsk: Wydawnictwo Harmonia.

Mass, V. (2007). Integracja sensoryczna a neuronauka - od narodzin do starości. Warszawa: Wydawnictwo: Fundacja Innowacja.

Mass, V. (2016). Uczenie się przez zmysty. Gdańsk: Wydawnictwo Harmonia.

Rozporządzenie Ministra Edukacji Narodowej z dnia 28 lutego 2019 r. w sprawie szczegółowej organizacji publicznych szkół i publicznych przedszkoli (Dz.U. 2019 poz. 502).

Polskie Stowarzyszenie Terapeutów Integracji Sensorycznej http://www.pstis.pl/pl/html/index.php?str=podstrona_slownik [data dostępu: 2021-01-17].

\section{SUMMARY}

\section{The importance of sensory integration therapy in the functioning of children with autism spectrum disorder in the intellectual norm (based on the example of students from the Special Primary School No. 2 in Bytom)}

Special Needs Primary School No. 2 in Bytom is a place of study for children from the spectrum of autism and hearing loss in the intellectual norm. As part of revalidation classes, a variety of therapies are conducted. Research was carried out to determine the importance of sensory integration therapy on the quality of functioning and educational progress of students. The conclusions obtained from the research are the basis for determining the further form of therapeutic work.

KEY WORDS: Autism, sensory integration therapy, primary reflexes disorders, therapy 